\title{
Wellcome Trust makes it personal in funding revamp
}

\section{科学者個人を支援する研究助成金 英国財団の新しい試み}

\section{Natasha Gilbert}

Nature Vol.462(145)/12 November 2009

生物医学研究の支援を目的とする民間団 体として英国最大の規模を誇るウェルカム トラストは、その助成制度の抜本的な見 直しをはかっている。

助成金を申請する研究者はこれまで、 それを使って 3〜 5 年の間に行おうとす る研究の内容を詳細に説明する申請書を 提出しなければならなかったが、ウェルカ ムトラストは、このような申請書をやめよ うとしている。個々の研究プロジェクトで はなく、研究者個人を、より長期的に支 援していくためである。ウェルカムトラス トの理事である Mark Walport は、「科学 を支援する最良の方法は、人を支援する ことだからです」という。

ウェルカムトラストが若手研究者とベテ ラン研究者のために新たに設ける研究者 奨励金制度では、いずれも主として面接 により、研究者本人とそのアイディアを評 価し、5〜 7 年にわたり助成を行う。申 請の際には、研究者はやはり申請書を提 出しなければならないが、その中で「個々 の実験をどのように行うつもりかを微に 入り細にわたって説明する必要はありませ ん」とWalport はいう。

Walport は、審査の際に重視する点を 変えることで、申請を行う研究者が大きな 科学的問題提起を行い、その問題が重要 である理由を示すことに集中できるように し、その問題にいかにして取り組んでいく つもりであるかは面接の際にじっくりと聞 き出していきたいと考えている。

ウェルカムトラストの新しい研究者奨励 金は、以前からある研究者助成金をべ一
スにしている。ウェルカムトラストの研究 者助成金は、ほとんどの支援団体の研究 者助成金と同じく、学術研究機関で有給 の地位を得ている研究者を支援するため のものではない。「研究者助成金への申 請者の面接では、申請者は自分の主張を 明らかにする機会を与えられ、私たちは彼 らにひらめきや独自のアイディアがあるか どうかを十分に審査することができます。 私たちは、有給の地位を得ている研究者 もこの制度の対象にすることで、彼らに十 分な支援をしたいのです」とWalport は いう。奨励金を獲得した研究者は、申請 の際に提案した研究に限らず、自分がや りたいと思うどんな研究にもそれを使うこ とが許されることになる。

新しい研究者奨励金の具体的な金額は まだ確定していないが、現在のプロジェク トやプログラムへの助成金と同程度の額 になりそうだ。ちなみに、2008 年のこう した助成金の総額は約 1 億 1000 万ポン ド（約 160 億円）だった。研究者奨励金 の第 1 回の申請は 2010 年の秋に行われ、 助成は 2011 年の初頭に始まる予定であ る。Walport によると、今回の制度改革は、 英国の多くの研究支援団体の問題である、 助成規模の小ささと助成期間の短さに対 する科学者からの不満に応えるためのも のであるという。

新しい研究者奨励金が従来の支援制度 に比べて広範に及ぶものになることを考え ると、支援を受けられる科学者の人数は 現在よりも少なくなるだろう。しかし、英 国ミルヒルにある国立医学研究所の所長
であり、過去に何度もウェルカムトラスト から助成金を受けたことがある Jim Smith は、「2 人や 3 人に不十分な助成をするよ りも、1 人に十分な助成をしたほうがよい のです」という。彼はまた、ウェルカムト ラストの新しい支援制度がうまくいけば、 ほかの研究支援団体も同様のアプローチ を考慮するようになるだろうと付言する。

ウェルカムトラストによると、同様のシス テムを採用している研究支援団体は、英 国内にはほかにないはずであるという。け れども米国メリーランド州チェヴィーチェー スのハワード・ヒューズ医学研究所 $(\mathrm{HHMI})$ は、1980 年代後半から同様のシステム を採用している。HHMI は現在、3 年ごと に、大きな科学的問題について概説する 簡単な申請書と、より詳細な面接に基づい て、総額約 6000 万ドルの助成を行ってい る。助成金を獲得した研究者は、 5 年の間、 自分がやりたいと思うどんな医学研究にも これを自由に使うことができる。HHMI の 副所長にして科学最高責任者である Jack Dixon は、「従来の助成制度では、助成金 の申請の際に提案した分野とは違った研 究を行う研究者は、いい顔をされないの が普通です」という。彼はまた、研究者が 研究を進める過程で新たに得た知見を掘 り下げる自由を認めることが「よりよい科 学」を生むともいう。Smith は、このアプ ローチのほうが正直であるという。なぜな ら、助成金を申請してから研究に着手する までの間に科学は進んでしまっているのが 普通であるからだ。（三枝小夜子 訳） 